\title{
REDESIGN AND IMPROVEMENT OF SUPPORT PROCESSES TO IMPROVE BUSINESS PROCESSES IN CRISES - CASE STUDY: WATER AND SEWERAGE SPLIT COMPANY
}

\author{
IVAN PERONJA
}

\begin{abstract}
:
Business process management (BPM) in partially process oriented companies, such as public utility companies and Vodovod i kanalizacija Split are, in crisis, requires from top management the redesign of business processes and primarily of business activities which flow through support processes. Since all the activities and changes in BPM are human based, it is essential to strenghten the support sector. IT management, changes in human resources, increasing the level of power and authority, disciplining activities in financial flow and improvement of controlling. In this key study, activities that have been undertaken for the past three years by top management, have brought up to the improvement of all business performances of the company, especially financial ones. Activities, undertaken by top managemant, have streghten the authority of IT sector, so the processing time of consumers' requests and reports has been reduced by $40 \%$, internal fluctuations of the employees and working efficiency have been increased by $32 \%$, and delegating the authority and power to middle management has been increased, which again brought up to reducing the decision making operational time. More evident public procurement, strenghtening the controlling, better payment conditions and adequate desposition of available fiancial resaurces have improved the efficiency of the company on the whole and financial performances have been improved by 105 $\%$.
\end{abstract}

\section{Keywords:}

business process management, redesign of support processes, crisis, financial performances, public utility company

JEL Classification: M20

\section{Authors:}

IVAN PERONJA, University of Split, Department for Professional Studies, Croatia, Email: iperonja@net.hr

\section{Citation:}

IVAN PERONJA (2015). REDESIGN AND IMPROVEMENT OF SUPPORT PROCESSES TO IMPROVE BUSINESS PROCESSES IN CRISES - CASE STUDY: WATER AND SEWERAGE SPLIT COMPANY. International Journal of Business and Management, Vol. III(2), pp. 45-65., 10.20472/BM.2015.3.2.004 


\section{INTRODUCTION}

This paper will discuss the contribution of redesign and business process improvements in overall organizational performance, with special emphasis on improving the support process. In fact, during the economic crisis, many traditional organizations, such as public utility companies predominantly are, have taken actions to make their business activities comply with the requirements of the changing and uncertain environment. Undertaken actions have mostly been based on putting financial performances under control. However, the real answer for improving the business performance of the organization lies in an adequate organizational structure that meets the principles of efficiency, flexibility, optimization, integration and teamwork. Unfortunately, the observed organization of the observed public utility company has all the characteristics of functionally oriented organization. Although it is true that the observed public utility company has all the characteriscics of the functionally oriented organization, organizational management managed to improve performances, maturity and flexibility of the organization by reducing the level of management, integrating services and departments, shortening the processing time and realization of requirements, investment in the IT development which resulted in increasing the degree of automation of business activities and awareness.

\section{CHARACTERISTICS, SIMILARITIES AND DIFFERENCES BETWEEN THE FUNCTIONAL AND ORGANIZATIONAL STRUCTURE}

\subsection{Defining business processes}

The literature finds various definition of business processes. Different authors have different approaches in defining business processes, from extremely vague definitions to very specific ones. Definitions described by a business process as a closed set of activities undertaken in response to an event that would generate a final result can often be found in literature.There are more specific definitions that are based on the notion that the business process needs to include all the final expectations of interested parties, and very specific definitions that define business processes as an interaction between people, equipment, methods and controls to achieve the specific goal. Wesner, Hiatt, and Trimble define the process as one or more tasks that transform a set of inputs into a specific set of outputs for another person or process, through a combination of people, procedures and tools ${ }^{1}$. Schurter ${ }^{2}$ on the other hand, defines business process as a specific way of organizing functions that are performed in the organization. In many cases, business processes exist within a functional segment of the organization. It is important to know that business processes are not measured in numerical sizes. Business processes often represent a particular business function that is deeply integrated into the workflow of the process.

\footnotetext{
${ }^{1}$ Wesner, J.W.- Hiatt, J.M. - Trimble, D.C.:Winning with Quality, Reading, MA: Addison- Wesley, 1994, p. 57 quoted by Džubur, S., Reengineering business processes to achieve business strategy, Thesis, University of Economics Split, Split, 2001, pp. 28

2 http://sapmag.com.hr/ quoted by Buble. M., The impact of organizational variables on the success of the business processes programme improvement, University of Economics in Split, Split, 2010, pp.19.
} 
M. Hammer and J. Champy ${ }^{3}$ focused on the impact of external processes, where process is emphasized as a set of activities which one or more inputs are exploited for and it produces an output thus creating consumer value.

Business processes emphasize the benefits that consumers have from a continuous repetition of the transformation of inputs into outputs.

It can be generally said that the business process is a framed sequence of interfunctional activities that develops in certain circumstances where its beginning, development and end can clearly be identified. All that with the goal of creating new value for the consumers.

By defining bussiness processes, most authors share a mindset that bussiness process is an interaction between different people, equipment, methods and resources in order to achieve the new value for the consumer throughout the transformation of inputs into outputs ${ }^{4}$.

To different definitions of business processes are attached different types of the same.The basic division of the business process involves three types of processes: control process, core processes and support process 5 .

\section{Figure 1. Types of business processes}

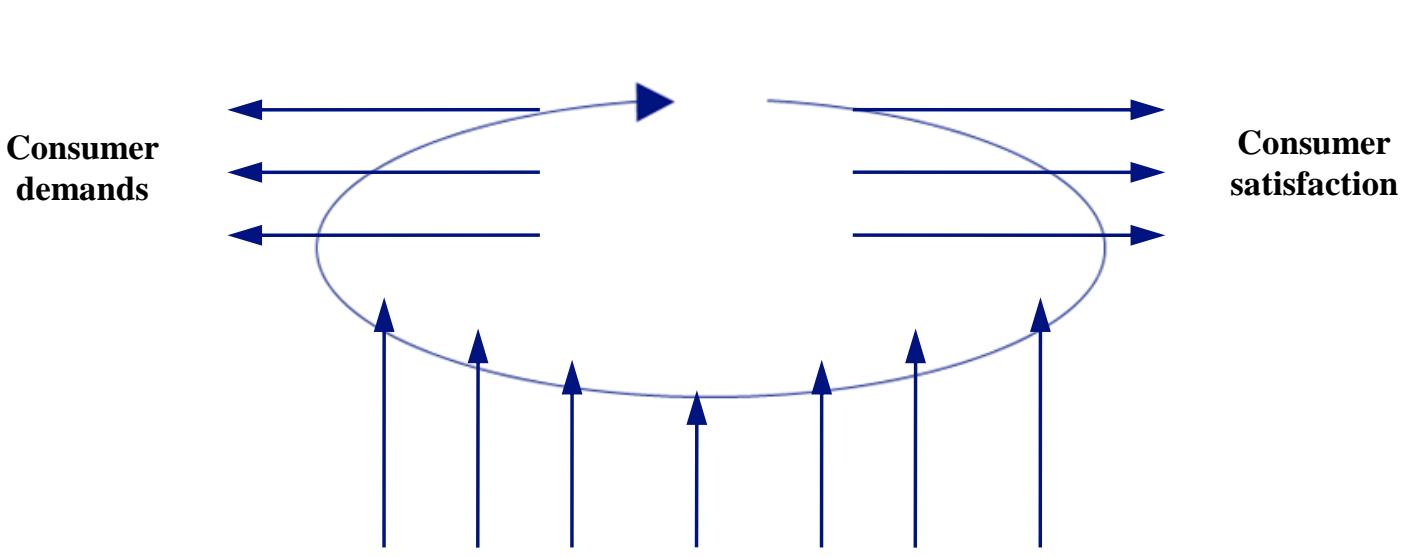

Support processes

Source: Buble. M., The impact of organizational variables on the success of the business processes programme improvement, University of Economics in Split, Split, 2010, pp.21

Characteristic of menagement business processes is that they are important for the performance of core business processes as well as for the support processes. The management processes are commonly called vertical processes with regard to their

\footnotetext{
3 Enström, J., Developing Guidelines for Managing Processes by Objectives, Thesis, Luleä University of Technology, Luleä, 2002, pp. 13, quoted by u Hernaus, T., Transformation of classical organization into processoriented organization, Thesis, University of Economics in Zagreb, Zagreb, 2006, pp. 149.

${ }^{4}$ Markić, B., Tomić, D., Building software agents for market segmentation, Baden Beden, 2006, pp.1 quoted Buble. M., The impact of organizational variables on the success of the business processes programme improvement,University of Economics in Split, Split, 2010, pp.19

5 Buble. M, The impact of organizational variables on the success of the business processes programme improvement, University of Economics in Split, Split, 2010, pp.21
} 
relevance, comprehensiveness, and direction of their activities. These are usually processes in the development, planning, providing resources and management structure of the entire organization.

The core business processes are characterized by a focus on satisfaction of external consumers by directly adding the new value to the product or service. The function of the core business processes is to fulfill consumer demands and to generate consumer satisfaction.

Product or service, as a final output of the entire business process, gets its confirmation on the market. Core business processes are often called horizontal business processes because of the need to integrate plans and products into the business process.

The difference between the core business process and support processes is in the focus on creating consumer satisfaction within the organization itself, which is one of the main characteristics of the support processes. Support processes create added value for final consumer, but in an indirect way. They generate added value by providing support to core business processes. These are support processes whose main role is to meet the needs of core business processes.

However, the division of processes into the central processes, support and management processes is also known ${ }^{6}$.

Processes characterized by meeting the needs of final consumers are called central processes.

What is more, all processes that aim to meet internal needs of the organization, such as the needs of employees and production processes need to be called support processess.

All those processes that in any way affect the central processes and support processes are called management processes.

One of the business processes divisions is the one which divides the business processess into operational processes, support processes, the process of determining the direction and management processes. ${ }^{7}$

Figure Chyba! $V$ dokumentu není žádný text $v$ zadaném stylu.. Four types of bussiness processes according to Wienclawu

Operational processes

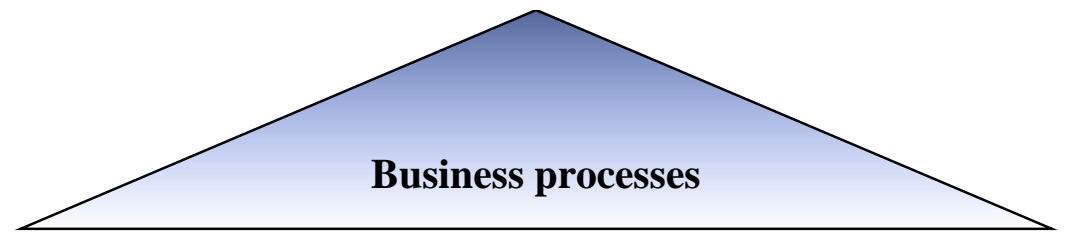

Process for determining the direction

Support processes

\footnotetext{
${ }^{6}$ Buble, M., Management, EFST, Split, 2000, pp. 225

${ }^{7}$ Wienclaw, R. Operations \& Business Process Management, Research Starters - Business. Ipswich, Great Neck Publishing, 2008, pp. 2-3., quoted by Buble. M The impact of organizational variables on the success of the business processes programme improvement, University of Economics in Split, Split, 2010, pp. 23
} 
Source: Buble. M. , The impact of organizational variables on the success of the business processes programme improvement, Faculty of Economics in Split, Split, 2010, pg. 3

Those processes that allow the execution of tasks, and include all the phases that precede the production of goods or services are called the operational processes. Processes that ensure the execution of operational processes are called support processes, and they include technology, human and financial support.

Those processes that affect organizational strategy, marketing and that manage the changes are referred to as determining the direction, while the management processes reffer to decision making and communication activities of the organization.

Review of business processes:

In order to understand business processes, they should be described and documented as precisely as possible. There are different ways of describing business processes, and one of the possible ways is: ${ }^{8}$

- Text description

- Cybernetic view

- Network Diagram

- Process diagram

\section{Text Description}

In complex processes, text description is very impractical, immense and complicated. It is very often used in combination with process diagrams when certain functions and events in business processes are described in details. Generally speaking, it can be said that it is very rarely used due to the reasons of impracticality and the nonapplicability to complex systems.

\section{Cybernetic view}

Cybernetic view includes images in which each process has its own input and output. Between them certain activities carried out by people using specific methods and equipment take place. In every process we find a large number of elements and their interrelationships, and the most important among them are the human resaurces, the means of order and methods.

Without these key elements there is no action nor any process. Of course, it is reasonable to expect the emergence of many other elements that indicate its characteristics and specific differences among specific business processes. Fundamental role in every process is a human role, because it is the man who designes the process, runs it, takes part in it, determines its characteristics and guidelines, and he supervises it.

\footnotetext{
${ }^{8}$ Milanović, Z., model of business processes re-engineering, FESB, Split, 2005, pp. 26.
} 
Figure 3. -Display of cibernetic view of bussiness processes

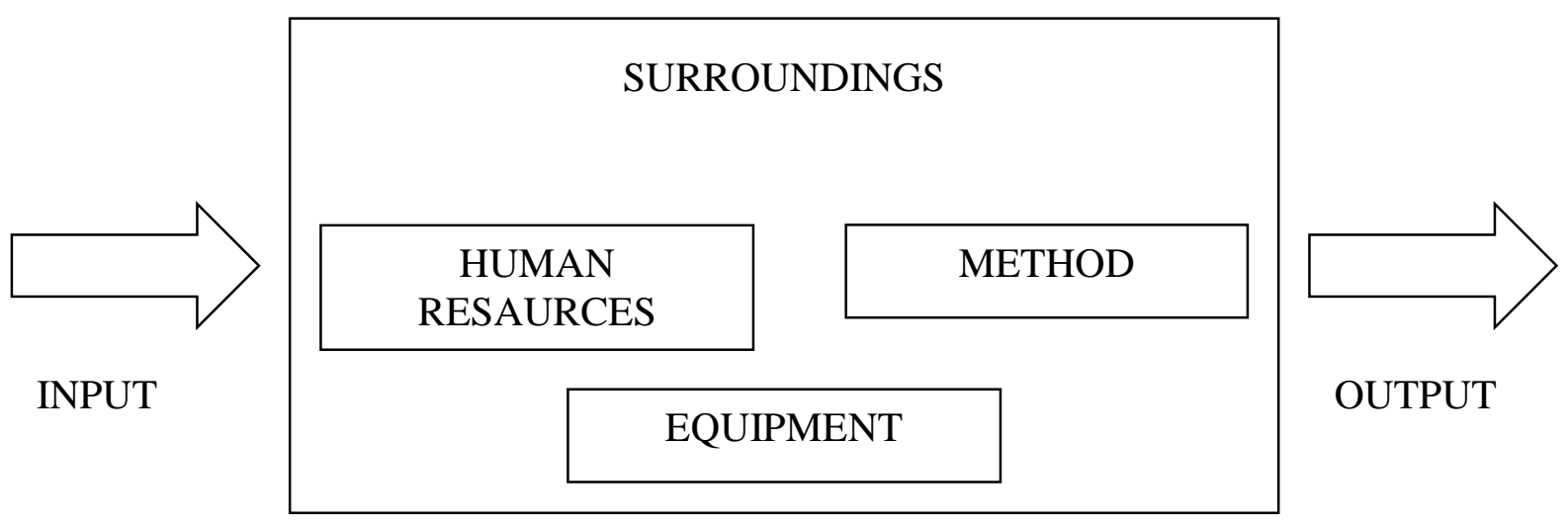

Source: Milanovic, Z., Model of business processes re-engineering, FESB, Split, 2005, pp. 26

It is important to focus on the smoothing of process. To achieve a smooth process at all its stages, it is necessary to adapt its key elements, i.e. employees. Selected methods, like technologies that precisely define the place, the time and the way the activities are done, make contribution to smooth process.

Network diagram

Network diagram shows the flow of business processes and the duration of individual operations, and it is very similar to Gantt diagrams. It is often used in the implementation of large and complex systems where there is need to harmonize numerous activities and events. It is very similar to the technique of network planning that takes place in three phases. The first phase consists of recognizing logical dependency work. Arrows are used to denote activities, and circles represent the state at the beginning and at the end of individual operation. In the second phase of network planning, estimated time to perform a specific job is determined. During the third phase, funds for work, labor and total costs are taken into consideration. 


\section{Figure 4. - Display of network diagram of business processes}

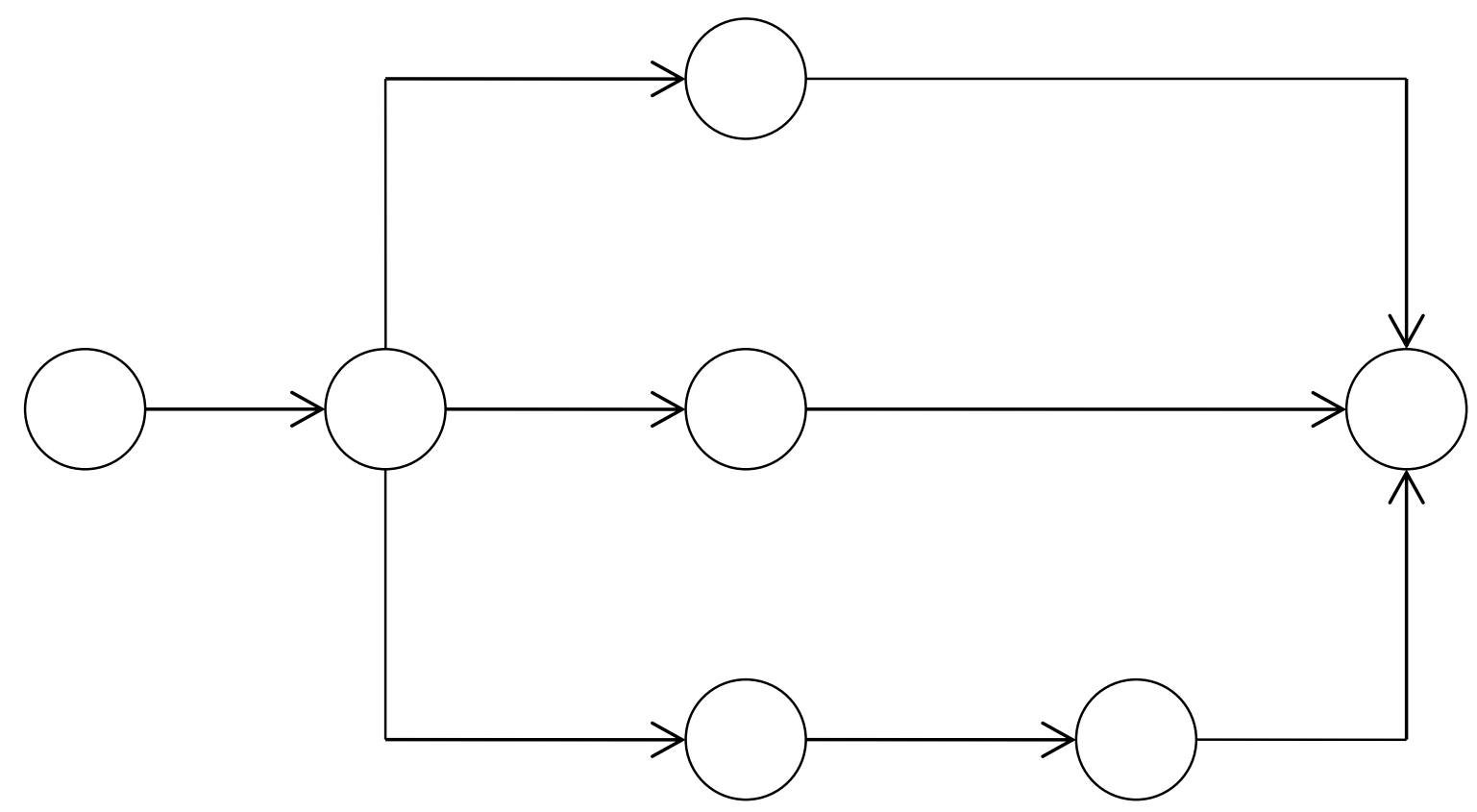

Source: Milanovic, Z., model of business processes re-engineering, FESB, Split, 2005, pp. 27

\section{Proces diagram}

Process diagram is a diagram of business activities that consists of a series of logically connected symbols that are not standardized and each software or any other tool has its own prescribed symbols through which the activities are displayed. Since business processes are complex, proces diagram is commonly used to present the business process at multiple levels. If a process consists of several lower-level processes, a new process diagram is created to complete the picture of the entire system in a simple and more effective way, so that the business demands are understood. Today, the process diagram as a way of presentation is used very often for the design, presentation, and the reengineering of business processes. The main characteristic of this model is a clear, precise and simple way of describing business processes through the prism of the events that follow the appropriate functions for which there is a particular performer.

\subsection{The concept of process-oriented business organization}

In the world of research, word process has been extremely popular. That affected the development of many definitions of the business process term, mainly based on literature dealing with business process reengineering which emerged in the 1990s.

Changes in the competitive global climate during the 21st century have increased the awareness of business processes as one of the most important concepts of modern management. There are more and more organizations with the process structure, and the procedural way of doing business becomes more present every day, so nowadays it is almost indispensable in the business. 
Frequent integration of process approach in the management structure presents a focus on achieving results. It has the direct impact on the operational level, all with the aim to meet the expectations of consumers and other stakeholders. ${ }^{9}$

Various process approaches have been found in the literature for the past decades, and each of them with insufficient systematic explanation.

Procedural issues were discussed in many economic theories: organization theory, strategic management, production management and group dynamics and the study of managerial behavior.

Some authors have attempted to show the process as a collective phenomenon, focusing on theoretical or methodological claims. But they failed to fully embrace the concept of process philosophy. ${ }^{10}$

However, when all these theories and the different attitudes are taken into consideration we can understand the organization and management practices. Undoubtedly, the processes allow and provide conventional, advanced level of analysis. Business processes consist of a variety of interrelated tasks, which enable us to detect so-called black box companies, with the purpose to avoid the frequent phenomenon of non-scrutinizing all parts of the organization.

Most previous researches have not focused on combining the methods of the individual approach and the approach that meets the needs of the whole organization. Model of process perspective contributes to achieving the necessary integration. Its aim is to bring the existing, real working practice to an explicit link with the overall functioning of the organization. The new process approach has given a new view of management position, allowing managers position to become significantly more rational and clearer. 11

Given the different views of process solutions, it is necessary to consider some important theoretical definitions of an organization focused on business processes. Foundations of process concept can be found in the work and contribution of W.E. Deming, M.E. Porter, T.H. Davenport and J. Short, M. Hammer and J. Champyja, V. Grover, R. Coombs, R. Hull, F. Ostroff and many others: ${ }^{12}$

W.E. Deming believed that an organization focused on business process functions as a set of processes that need to be understood, stabilized and improved. In his claims, M.E. Porter stresses the importance of the value chain, while process-oriented organizational structure with its design should correspond to the strategic importance of supply chain processes. According to M. Imai the organization must be able to solve the problems and it should be improved continuously. He emphasizes the processes and process-oriented way of thinking.

\footnotetext{
${ }^{9}$ Levi, M.H.(2002), The Business Process (Quiet) Revolution: Transformation to Process Organization, Interfacing Technologies Corporation, pp.1. as cited. in Hernaus, T., Transformation of classical organization into processoriented organization, Ph.D Thesis, University of Economics in Zagreb, Zagreb, 2006, pp. 41

http:// www.interfacing.com/ rtecontent/document/CreatingProcessOrganization03.pdf

${ }_{10}$ Bosilj Vukšić, V., Hernaus, T., Kovačić, A., Business process managemant, Školska knjiga, Zagreb, 2008, pp.21

${ }^{11}$ Garvin, D.A., The Processes of Organization and Management, MIT Sloan Management Review, Vol. 39, No. 4. pp.34, quoted by Hernaus, T., Transformation of classical organization into process-oriented organization, Thesis,University of Economics in Zagreb, Zagreb, 2006, pp. 41

12 Lockamy III, A. McCormak, K.P.(2004), The development of a supply chain management process maturity model using the concepts of business process orientation, Supply Chain Management: An International Journal, Vol. 9, No. 4, pp. 273, quotedby Hernaus, T., Transformation of classical organization into process-oriented organization, Thesis, University of Economics in Zagreb, Zagreb, 2006, pp. 41
} 
P. Drucker believes that the organization must be based on task-oriented teams that are engaged in linking the activities or processes that exceed old organizational frames and end with the consumer. M. Hammer believes that the process-oriented organization focuses on interfunctional set of activities that require one or more inputs and produce output as the value for consumers. A group of authors headed by $\mathrm{V}$. Grover carries out the belief according to which the organization should be based on process-oriented structure, measures, award systems and resource allocation. For E.H. Melan process-oriented organizations look at their operations as a set of interrelated tasks with specified inputs and outputs.

According to J. McCabe and T. DeToro process-oriented organizations are composed of a series of functional processes linked through the organization and assisted by cross-functional work teams. T.H. Davenport stated that the process organization puts emphasis on the horizontal view of the business organization which is the lineout of the organization with inputs at its beginning and outputs and consumers at its end. And this is how the process-oriented organizations are most often understood.

The successful construction of the above models requires a new approach and a new way of thinking about the organization that will result in dramatic improvement in performance. This thinking is generally defined as an orientation to business processes. ${ }^{13}$

The ultimate goal of process orientation is to establish the process-oriented structure. The organizational form whose core is based on key business processes and the flow of business activities is often referred to as the horizontal organization. ${ }^{14}$

There are many differences in what people consider to be the process-oriented organization. The key processes such as a new product development and a supply chain management are most often the basis of an organization.

Execution of each activity involved in the process requires the gathering of employees in the product team responsibe for the overall process, and in the end responsible to the process owner.

\footnotetext{
${ }^{13}$ Bosilj Vukšić, V., Hernaus, T., Kovačić, A., Business Process Management, Školska knjiga, Zagreb, 2008, pp.23

${ }^{14}$ Nikolenko, A., Kleiner, B.H. (1996), Global trends in organizational design, Work Study, Vol. 45, No. 7, pp. 24 quoted by Hernaus, T., Transformation of Classical Organization into Process-oriented Organization, Thesis, University of Economics in Zagreb, Zagreb, 2006, pp. 42
} 
Figure 5. - Display of business processes flow- the traditional and processoriented approach

\section{Traditional approach}

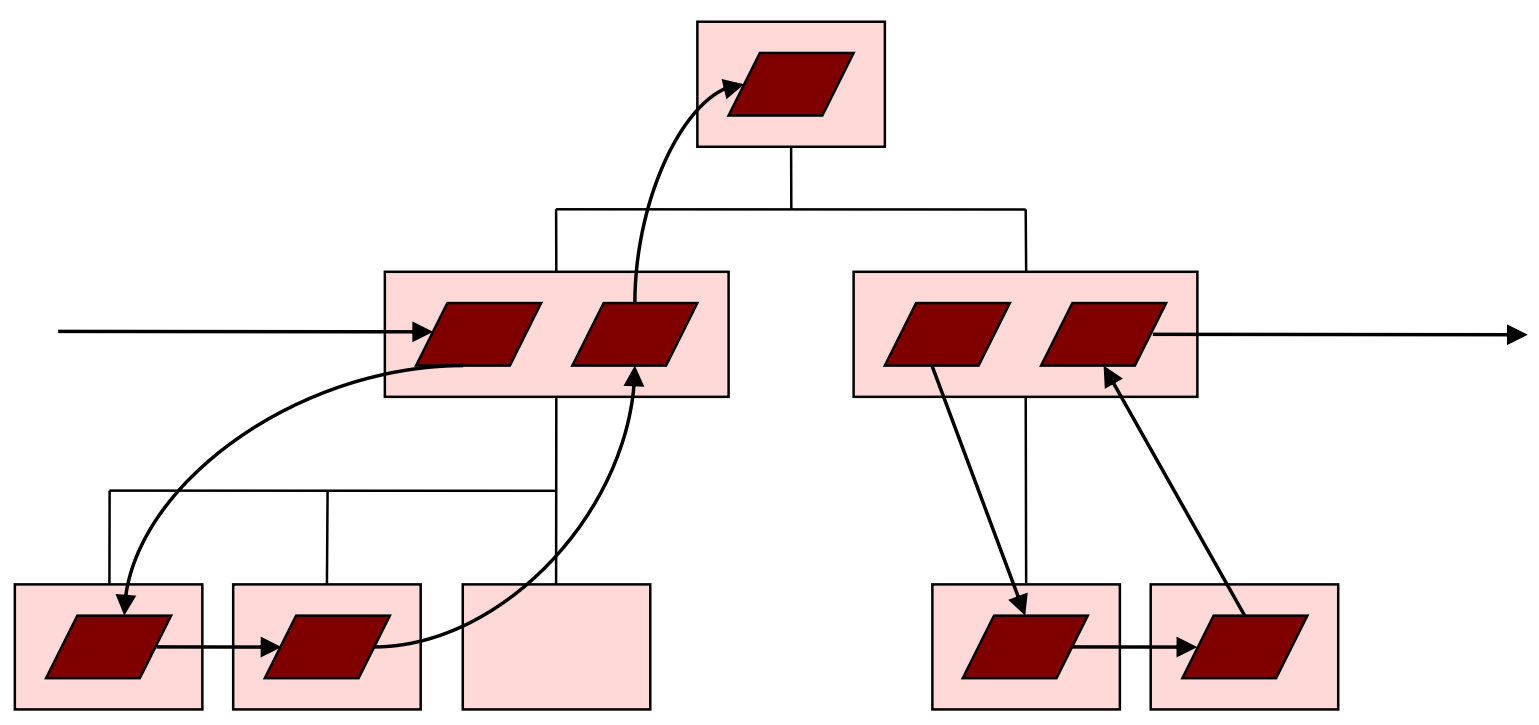

\section{Process-oriented approach}

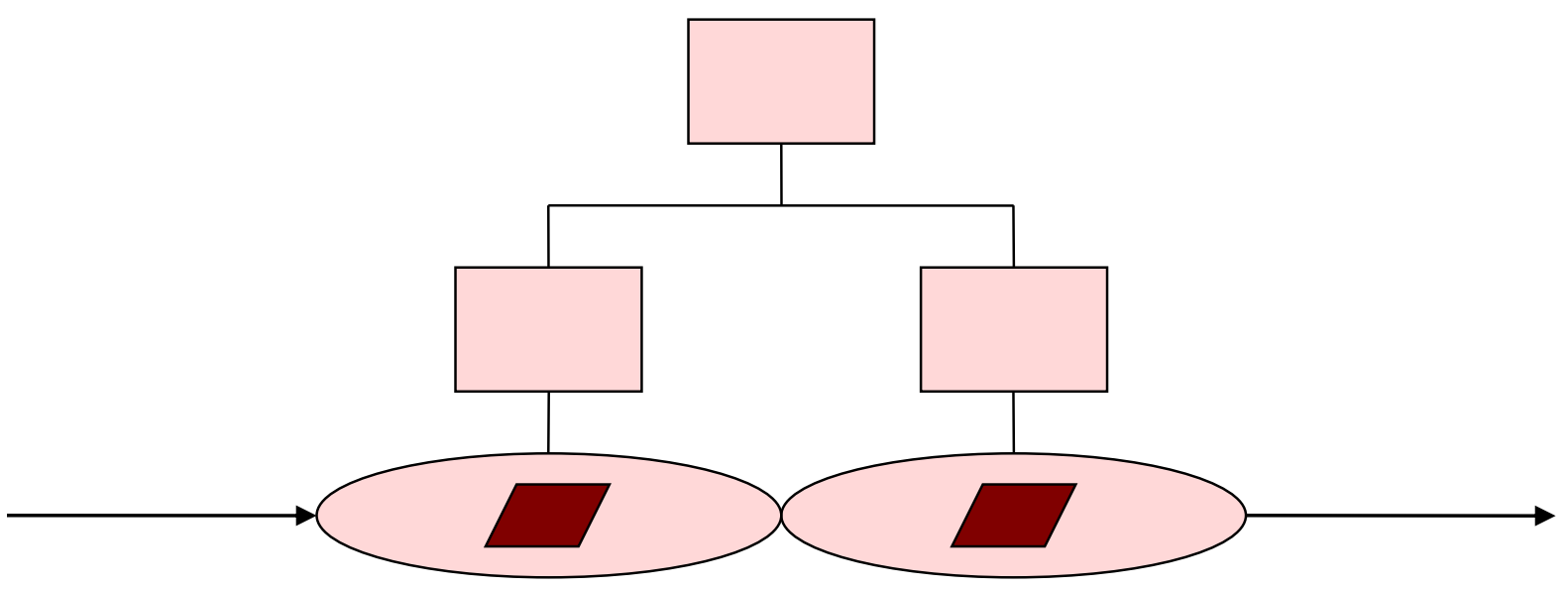

Source: Kai, SA, Organizational Change and Information Technology, Doctoral Thesis, Göteborg University, Göteborg, 1999, pp. 60 quoted by Hernaus, T., Transformation of classical organization into process-oriented organization processes, Thesis, University of Economics Zagreb, Zagreb, 2006, pp. 43

We are often encountered with the situation where the process organization structure is identified with the business process reengineering. An organization that is based on processes and that is process-oriented is not synonymous with business process reengineering. 
Process-oriented organization places more emphasis on global, social and technical aspects of human dynamics, and less on technology, business tools and technique itself. This approach should be applyed on all levels of the organization, not only on a process or implementation of a new IT solution. ${ }^{15}$

Process organizational structure is closely related to functional organizational structure, but again they are different from each other. The frame that represents the functional organizational structure is what they have in common, and it operates within the organizational structure of the process. ${ }^{16}$

The process should be viewed altogether, from its beginning to its end, and then its value will be visible.

If the previously said is combined with a range of new information technology, we get a new value with the possibility of redisigning the entire process. The changes are usually linked in a domino effect rule, which means that changes within a single function can cause changes in all the remaining functions.

However, most business people do not even think about the business processes because they are focused on the execution of daily tasks and obligations. This approach is not good for the future of the organization.

If there is a manager responsible for dealing with the process in its entirety, unlike many operational and functional managers, it is reasonable to expect to overcome the resistance to change existing processes more easily.

Some of the principles of process management are: ${ }^{17}$

- Focus on customers.

- Cross-functional approach

- Teamwork.

- Continuous improvement.

- Clear responsibilities and competence.

- operationalized goals.

- Management by objectives.

- Compensation System.

- Entrepreneurship.

People are the foundation of turning to a new process-oriented business concept, so all agencies and departments that decide to implement the concept of process-oriented business must be aware and ready to accept the attacks as a reaction to the introduction of a new concept.

The implementation of process orientation is not necessarily done at the enterprise level, but implementation can be performed on smaller organizational units, as well as on inter organizational level at which we cross onto supply chain management.

\footnotetext{
${ }^{15}$ Crosetto, G., Mavazaga, J., The Process-Based Organization-A Natural Organization Strategy, HRD Press, Amherst, 2005, pp. 1

${ }^{16}$ Sikavica, P., Novak, M., Business Organization, Informator, Zagreb, 1999, pp. 181-182

17 Osterle, H., Business in the Information Age: Heading for New Processes, Springer, Berlin, 1995, pp. 127-128, cited by Hernaus, T., Transformation of classical organization into process-oriented organization, Thesis, University of Economics in Zagreb, Zagreb, 2006, pp. 44
} 
Thus, the implementation of process orientation may as well be a multi-level, which means that the horizontal organization may apply on: ${ }^{18}$

- not just one company.

- the level of the entire organization.

- the number of different business units within the company.

- within a single business organization.

- a group of key processes within the business units.

- within the business unit on the operational level.

The concept of business processes is very popular and we are often faced with the fact that many organizations are called process-oriented, but there is still a large number of organizations whose organizational structure is functional or divisional with little or no orientation process. That is mainly because of the dominant form of production.

Nowadays, more and more organizations and business people recognize the value of the concept of process orientation. But the traditional focus on the execution of tasks is a great obstacle to a more dynamic understanding of the importance of implementating the process-oriented concept into organization.

\subsection{Characteristics of process orientation}

When the basic characteristics of the process orientation are determined, it is important to emphasize the lateral communication as one of the most important ones.

Communication between departments is very important and necessary. Lack of communication between departments is one of the greatest dangers in implementing effective changes. Employees need to realize organizational goals, and just lateral communication and coordination between departments can eliminate barriers and meet organizational goals.

Lateral relationships affect the level of communication and coordination through organizational units. They are often not visible on the organization chart, but nevertheless they are an important part of the organizational structure. Since the purpose of process-oriented organization is business process management, lack of need for a large number management levels is considered natural. ${ }^{19}$

According to J.R.Galbraith the future organizations will be marked by importance of lateral integration and reducing the organization. Galbraith's attitude to future forms of organizational units is associated with the importance of the process that connects people and organizational units throughout the organization.

\footnotetext{
${ }^{18}$ Ostroff, F., The Horizontal Organization, Oxford University Press, New York, 1999, pp. 75-76, quoted by Hernaus, T., Transformation of classical organization into process-oriented organization, Thesis, University of Economics in Zagreb, Zagreb, 2006, pg. 45

19 Daft, R. L., Organization Theory and Design, Thompson, Mason, Ohio, 2004, pp. 91, cited by Hernaus, T., Transformation of Classical Organization into Process-oriented Organization, Thesis, University of Economics in Zagreb, Zagreb, 2006, pg. 59
} 
In a traditional organizational model functional units are integrated by a general manager. They are more and more replaced by organizational forms that can be used to integrate multiple functions. ${ }^{20}$ Lateral processes are not a substitute for vertical processes. Nowadays, there are operational requirements that an increasing number of decisions is delegated and made on lower hierarchical levels.

Process-oriented organizations which implemented process-oriented organizational structure in order to achieve improvement of the entire business should establish a special unit (ministry, department, sector, etc.), which will concentrate on implementation, monitoring and controlling processes that occur during operations. ${ }^{21}$

Process-oriented organizations put main emphasis on business processes and are focused on the mission and goals of the organization. In the process-oriented organizations product teams are the basic organizational unit to carry out a wide range of tasks. Observing the complexity and the depth of the organization it can be considered a shallow organization with a highly decentralized way of governance. Flow of operational processes within a process-oriented organization is characterized by simple relationships with the very flexible use of technology. Employees' responsibility for the flow of process within the process-oriented organization is broad and it allows their further development. Their work is valued in accordance to their contribution to the organization. 22

Among other characteristics of process-oriented organization the role of the process owner as one of the key features, should be pointed out as well as scheduling objectives and resources of the organization through business processes.

This ensures that the functional units are as compatible as possible and able to respond to the demands of business processes that support.

Many authors have systematically tried to show the basic features of the process approach, and authors such as P.E.D Love and A. Gunasekaran came up with 10 principles that are the essence of horizontal organization: ${ }^{23}$

1) Organizing is performed around the business processes.

2) Lowering the hierarchy by reducing the parts of the workflow and the number of activities that do not create added value.

3) Providing authorities to processes and process measurement indicators.

4) Consumer satisfaction is associated with the goals achieved.

5) The basis of organizational performance are teams, not individuals.

6) Combination of managerial and non managerial activities.

7) Multiple competencies as a rule, not as exceptions.

\footnotetext{
${ }^{20}$ Galbraith, J. R., Lawler III, E. E. I sur., Organizing for the future, Jossey-Bass, San Francisco, 1993, pp.109

${ }^{21} \mathrm{http}: / / w w w . p r o j e k t u r a . o r g / g u e s t s / g u e s t ~ b o j a n . h t m ~(20.06 .2011$.

22 Bosilj Vukšić, V., Hernaus, T., Kovačić, A., Business Process Managemant, Školska knjiga, Zagreb, 2000., pp.55

${ }^{23}$ Love, P.E.D., Gunasekaran, A., Putting an Engine into Re-engineering: Toward a Process-oriented Organisation, International Journal of Operations \& Production Management, 1998, Vol.18, No. 9/10, pp. 152.-166. cited by Hernaus, T., Transformation of Classical Organization into Process-oriented Organization, Thesis, University of Economics in Zagreb, Zagreb, 2006, pp. 60
} 
8) Training of employees is based on the "just-in-time"principle, and not on "you should know" principle; theyhave to help other team members.

9) Strengthening business relationships with consumers and suppliers.

10) Rewarding team results, not only individual success.

These ten principles are largely compatible with the basic characteristics of horizontal organization, which was defined by F. Ostroff, one of the ideological founders of this organizational form. He divided characteristics into two categories: one related to the organizational design and one related to institutionalization, i.e. the implementation of the concept in the organization.

R.L. Daft includes a structure that is formed around key processesnot around tasks into the basic characteristics of process-oriented organization. Independent product teams are the basis of organization design and performance, and accountability for each key process is assigned to the owner process. Every team member is trained so that he could perform tasks of other team members, using the skills, tools, authority and motivation. By setting new challenges for the teams, they are enabled to work more flexibly and they are given greater freedom in thinking. It should be emphasized that the effectiveness of organizations is measured by the realization of planned objectives, and satisfaction of end consumers who are given the role to be leaders of the organization. Directing the culture whose main characteristics are openness, trust and cooperation to continuous improvement of overall operations of the organization is enabled.

\subsection{The modern concept of business process management}

The science of systems is a relatively new field that is daily explored. But it is known that 5000 years ago arose viewpoint on the Chinese yin and yang, which attempted to link the logic and systems. Initiating and directing attention to business processes was initiated by M.E. Porter with known concept of value chain. During the time in Japan appeared a need to improve product quality in order to compete with U.S. producers. Further reflections on the business processes have led to a need for a radical redesign of business processes to improve distinct business indicators. Need for distancing and the gradual abandonment of the radical move of redesigning business processes was realized by $\mathrm{M}$. Hammer who has seen the benefits of business process management. He believed business process management to be the natural way of performing tasks in the organization.

\subsection{Business Process Management}

Apart from management theory, in today's business world, more attention is paid to business process. It is hard to imagine today's successful business without analysis and business process management. Analysis and business process management represent a tool which can achieve competitive advantage. The traditional understanding of management and organization, which had previously been functional and is based on separate business units or functions, among which was minimal 
communication, is abandoned. A new business context in which are very important intangible resources, i.e. processes, is created. Process approach proved itself as a suitable model for analyzing and modern business management. It is creativity and knowledge of, , the fundamental principles of organizational theory and models of competitive advantage. Routine management and use of stereotypes has become a matter of the past. Generating of knowledge, learning, innovation, creativity and competence of the workforce are becoming a necessity for the realization of sustainable competitive position. Management of intangible resources is articulated as a separate discipline within which the processes are an essential component.

"If it doesn't make three people angry, it isn't a process." 24

Busines process management is a systematic approech to managing and improving an organization's business by the active, coordinated management of all aspects of the specification, design, implementation, operation, measurement, analysis and optimism of business processes in order to effectively and efficiently deliver business objectives. ${ }^{25}$

One of the common mistakes people make is confusing business functions for business processes. Business processes are by their nature interfunctional, in other words they include more functions. The functions are specific to certain departments which focus on certain skills or knowledges.

The most common examples are the production, sales, human resources, finance, etc.

There are three major trends that characterize business processes, such as: ${ }^{26}$

- Automation

- Integration

- Lifecycle Management

It is easy to come up with the idea, but to do a thing is a problem. Authoritative leadership can only lead to losing the idea or not realizing it in the best possible way. During the development of the concept of business process management, the transition from mechanical to semi-bureaucratic management teams, which require a large number of ordinary managers and effectively trained and prepared workers.

The initial focus of BPM is the automation of business processes using information technology. During the process of application BPM technology is often used incorrectly. Human resources and processes are key elements of BPM, and technology provides a support for the execution of planned objectives. It is important to implement BPM gradually and starting from a project within the organization itself. For quality implementation of the concept of BPM gradually within the organization, it is desirable to hire an external consultant. The organization must be ready to further develop and improve existing skills and experience of available human resources. Implementation of BPM is reflected on the business in a way that new values are generated for one field which is the business goal organization. BPM gradually should be seen as a tool which enables us to understand the organization through an expanded view composed of interconnected processes. One can say that BPM is in

\footnotetext{
24 Michael Hammer stated in discussion about defining business processes, cited by Davis, R., Brabander, E., ARIS Design Platform-Getting Started with BPM, Springer, London, 2007, pp. 3

${ }^{25}$ Davis, R., Brabander, E., ARIS Design Platform-Getting Started with BPM, Springer, London, 2007, pp. 7

${ }^{26}$ Davis, R., Brabander, E., ARIS Design Platform-Getting Started with BPM, Springer, London, 2007, pp. 10
} 
fact an approach which enables integrating changes in capacity of an organization using the human and technological resources. BPM is much more than software, more than a business process improvement and more than just modeling. It deals with items of management, i.e. an implementation and performance of processes which require analysis.

Current scientific and technical deliberations agree that there are significant differences between the traditional functional organization and process-oriented one. The difference between process and function can best be described the following way: process is defined as a spatially and temporally limited, framed sequence of business activities during which available resources are engaged with the aim of creating useful output for the end users with a clearly defined beginning and ending. ${ }^{27}$ Function is characterized by grouping related activities in which it is usually not possible to identify the output, so in that sense, the benefit to the end user is minor. ${ }^{28}$ Functions represent the lines of responsibility in the company, with divisions and departments acting like 'small organizations', while the processes are actually sets of activities undertaken by employees of the functional units and managed by functional managers. Functional units describe the flow of authority and responsibility, while processes describe the flow of business. ${ }^{29}$ From the previously mentioned the differences between the traditional functional organization and process-oriented organization arise, making it possible for the function to exist in the process concept but with the different aim. The function in the process approach gratifies the process which creates the value. It can be said that the functions are the elements which build organization and processes are the objectives for which the process-oriented organization exists. Author J.A. Byrne in his paper "The horizontal corporation" is the first to compare the vertical and horizontal organization. According to him, the vertical organization is the organization whose members are oriented and look to their authorities rather than to their end users. Loyalty and commitment are directed towards the functional silos, rather than organizational goals. ${ }^{30}$ The same approach is shared by other authors such as K.P. McCormacka and W.C. Johnsona. They emphasize the benefits of the process approach in a much broader perspective since the goal is the satisfaction of both, internal users in the organization and end users ${ }^{31}$.Differences between the functional and process organization can be detected at all levels, so the management of processoriented organization is focused on the systematic approach and coordination, measurement and improvement of all aspects of the process requiring continuous operation of cross-functional teams and increasing the degree of delegation of rights and powers to employees.

\footnotetext{
${ }^{27}$ Bosilj Vukšić, V., Hernaus, T.,Kovačić, A., Business Process Masnagement, Školska knjiga, Zagreb, 2008, pg.16

28 Oden, H.W., Transforming the Organization: A Social-Technical Approach, Quorum books, Westport, 1999 pg. 111

29 Harmon, P., Business Process Change: A Managers Guide to Improving, Redesigning, and Automating Processes, Morgan Kaufmann Publishers, San Francisco, 2003, pg 109, taken from Hernaus, T. Ph. D. Thesis, University of Economics, Zagreb, Zagreb, 2006, pg 93

${ }^{30}$ McCormack, K.P., Johnson, W.C., Walker, W.T., Supply Chain Networks and Business Process Orientation, St. Lucie Press, Florida, 2003, pg 19, taken from Hernaus, T. Ph. D. Thesis, University of Economics, Zagreb, Zagreb, 2006, pg. 94

31 McCormack, K.P., Johnson, W.C., Walker, W.T., Business Process Orientation-Gaining the E-Business Competitive Advantage, St. Lucie Press, Florida 2001, pg. 106 taken from Hernaus, T., Ph. D. Thesis, University of Economics, Zagreb, Zagreb, 2006.,pg. 94
} 
Table 4.1. Similarities and differences between functional and process -oriented organizational structure

\begin{tabular}{|c|c|c|}
\hline Category & $\begin{array}{l}\text { Traditional organizational } \\
\text { structure }\end{array}$ & $\begin{array}{l}\text { Process organizational } \\
\text { structure }\end{array}$ \\
\hline \multicolumn{3}{|l|}{$\begin{array}{l}\text { ORGANIZATIONAL } \\
\text { FOCUS }\end{array}$} \\
\hline The main focus & Business functions & Business processes \\
\hline $\begin{array}{ll}\text { Compliance } & \text { with } \\
\text { organizational goals and } \\
\text { mission }\end{array}$ & $\begin{array}{l}\text { Misunderstanding the } \\
\text { organizational mission } \\
\text { and goals }\end{array}$ & $\begin{array}{l}\text { The focus on } \\
\text { organizational mission and } \\
\text { goals }\end{array}$ \\
\hline Product & $\begin{array}{l}\text { Simple, standardized } \\
\text { product }\end{array}$ & $\begin{array}{l}\text { A flexible product } \\
\text { adjustable to the } \\
\text { consumer }\end{array}$ \\
\hline Employees' focus & $\begin{array}{l}\text { Employees functionally } \\
\begin{array}{l}\text { oriented to satisfying } \\
\text { superiors }\end{array}\end{array}$ & $\begin{array}{l}\text { Process-oriented } \\
\text { employees to satisfying } \\
\text { consumers }\end{array}$ \\
\hline \multicolumn{3}{|l|}{$\begin{array}{l}\text { THE STRUCTURAL } \\
\text { ELEMENTS }\end{array}$} \\
\hline $\begin{array}{l}\text { The basic organizational } \\
\text { units }\end{array}$ & Functions & Process teams \\
\hline Tasks & $\begin{array}{l}\text { Closely defined tasks and } \\
\text { functions }\end{array}$ & $\begin{array}{l}\text { Tasks and activities are } \\
\text { wide and flexible }\end{array}$ \\
\hline Management style & Supervision & Mentoring \\
\hline Key person & $\begin{array}{l}\text { Department Director, } \\
\text { Business Function }\end{array}$ & $\begin{array}{l}\text { The owner of the business } \\
\text { process }\end{array}$ \\
\hline Tall organization & High hierarchy & Shallow \\
\hline Type of structure & Bureaucratic & Organic \\
\hline \multicolumn{3}{|l|}{$\begin{array}{l}\text { OPERATIONAL } \\
\text { PROCESSES }\end{array}$} \\
\hline Workflows & Intermittent & Linked / Simplified \\
\hline (Sub)optimising & $\begin{array}{l}\text { Suboptimizing operations } \\
\text { due to the optimizing } \\
\text { individual functions }\end{array}$ & $\begin{array}{l}\text { Optimizing processes, } \\
\text { although they require } \\
\text { suboptimizing } \\
\text { functions }\end{array}$ \\
\hline Technology & Specific & Flexible \\
\hline Determining responsibility & The entity of error & The cause of error \\
\hline The purpose of control & Correcting mistakes & Lowering variations \\
\hline Measuring the success & Results & Results and processes \\
\hline
\end{tabular}




\begin{tabular}{|c|c|c|}
\hline Implementation of control & Post-control & Preventive control \\
\hline Allocation of resources & Competition & Common resources \\
\hline \multicolumn{3}{|l|}{ HUMAN RESOURCES } \\
\hline Employees' skills & $\begin{array}{l}\text { Individual and functional } \\
\text { specialization }\end{array}$ & Skill integration \\
\hline Reward system & $\begin{array}{l}\text { Based on the functional } \\
\text { contribution }\end{array}$ & $\begin{array}{l}\text { Based on the } \\
\text { organizational contribution }\end{array}$ \\
\hline Flexibility & No flexibility & Flexibility during changes \\
\hline $\begin{array}{l}\text { Way of managing human } \\
\text { resources }\end{array}$ & $\begin{array}{ll}\text { Human } & \text { resource } \\
\text { management } & \end{array}$ & $\begin{array}{l}\text { Developmen of human } \\
\text { resources }\end{array}$ \\
\hline Responsibility & Narrow & Broad \\
\hline COMMUNICATION & & Horizontal \\
\hline Direction & Vertical & Horizontal \\
\hline Flow & $\begin{array}{ll}\text { Barriers } & \text { between } \\
\text { departments } & \end{array}$ & $\begin{array}{l}\text { Organization without } \\
\text { borders }\end{array}$ \\
\hline $\begin{array}{l}\text { The most common form of } \\
\text { communication }\end{array}$ & The superior-subordinate & The supplier-consumer \\
\hline $\begin{array}{l}\text { Coordination between the } \\
\text { functions cooperation }\end{array}$ & $\begin{array}{lll}\begin{array}{l}\text { Functions } \\
\text { cooperating }\end{array} & \text { are not }\end{array}$ & Cross-functional \\
\hline Speed & Slow information flow & Fast information flow \\
\hline Understanding the work & $\begin{array}{l}\text { Understanding the work of } \\
\text { one's function }\end{array}$ & $\begin{array}{l}\text { Understanding the } \\
\text { connections with other } \\
\text { functions }\end{array}$ \\
\hline Distribution of information & $\begin{array}{l}\text { The information is not } \\
\text { regularly shared between } \\
\text { the functions }\end{array}$ & $\begin{array}{l}\text { Information of mutual } \\
\text { interest is routinely shared } \\
\text { between functions }\end{array}$ \\
\hline \multicolumn{3}{|l|}{ CULTURE } \\
\hline Changes & Maintaining the status quo & The tendency to changes \\
\hline The style of thinking & Short-term thinking & Long-term thinking \\
\hline Type of culture & Individual culture & Team work \\
\hline
\end{tabular}

Based on the information in the table, the supremacy of process in relation to the traditional organizational structure is visible. Because of the multi-layer diversity, it is recommended that these two organizational forms are analyzed in six categories as follows: organizational focus, structural elements, operational processes, human resources, communication and culture. 


\section{REDESIGN OF SUPPORT PROCESSES}

Support processes represent one process component in the flow of process activities. Why are redesign and improvement of support processes even approached? Support processes are "less important" in relation to core processes. All support processes have the owner. Support processes are like "fuse" which ensures the voltage, i.e. undisturbed flow of core processes. If a certain support process or its segment "pops out" and ceases to perform the function for which it was designed, the area where it ceased to function, the intensity and complexity can easily be detected. Any delay in the flow of support activities of core prcesses can be considered the bottleneck of the organization and it requires urgent intervention in redesigning that part of the process. Support processes are of smaller capacity, less importance and less impact than core processes, therefore the investments in their functioning are lower than in the core processes, which suggests lower costs for the organization. Support porocesses support the flow of activities of the main process and act under the principle of communicating vessels. The new support process takes over the function when the activity of certain support process ceases to function. In the observed organization all activities, apart from core processes, can be classified according to rank in the secondary process activity, and that must not be equalized with the mission of the organization. The goal of redesigning support processes is to significantly improve critical contemporary measures of success such as cost, quality, service and speed. ${ }^{32}$

\section{CASE STUDY "Vodovod i kanalizacija Split" Company}

"Vodovod i kanalizacija Split" Company is the organization with the status of trading company with limited liability for providing water supply and drainage. The founding rights belong to the City of Split. The company has been performing its duty in 4 cities and 9 municipalities for the last 120 years. It employs 429 employees, and with total annual revenues of approximately 30 million euros, the company operates positively. 40 employees have been rearranged inside the company, and 26 have been rearranged in the outer fluctuations. Company's management has begun the transformation of the organization from the traditional functional one into the processoriented organization. Total costs arising from the transformation of the organization amount to approximately 5 million euros. Benefits are already multiple, although the transformation began and is being carried out during the peak of the economic crisis, which causes additional costs of adaptation and rapid decision making. Effects of redesign of support process and transformation of the organization are visible in following:

- Simplified and shallower organizational structure

- Increased flexibility in the organization compared to other similar organizations

- Some departments and services have been closed down or annexed to others which shortened the processing time of end users demands, and increased the overall efficiency of the organization

\footnotetext{
32 Hammer, M., Champy, J., Company reengineering , Mate, Zagreb, 2004. pg. 34
} 
- Processing time of end users demands has been reduced by $40 \%$

- 2 million euros have been invested in the development of IT support, which has accelerated data processing, and tasks are delegated and controlled electronically

- Cost savings in the vehicle fleet are 50.000.00 per year

- Employees absence from work is $25 \%$ lower

- Employees efficiency is standardized and personal performance of each employee is electronically recorded, which resulted in increased efficiency of $28 \%$ for the organization

- Financial performances are substantially improved, and the company operates with a profit

- During 36 months the organization of the 4 million annual losses started to operate positively

- Decision making time on middle management level has almost been cut in half

- Transparency of public procurement has increased which has a direct impact on financial performance

- The level of business culture, maturity and capacity of the organization are upgraded to the level that the organization has become a leader of the organizations of the same kind

\section{CONCLUSION}

Based on all the analyzed factors and indicators, there are no circumstances and reasons why the traditional functional organization would not aspire transformation and implementation of process approach. Benefits of organizational transformation are numerous and they multiply on all organizational performances. Transformation cost is still several times lower than the benefits if the transformation is carried out professionally, if it is planned and controlled. Transformation is not possible without investment in employee training and development, investing in the IT sector and reducing the levels of decision making. There are real dangers connected to transformation of the organization, and the biggest danger is delaying the beginning of transformation. The modern process-oriented organizations are flexible, learning, competent, computerized and automated organizations with a highly developed control functions that quantify the individual and collective effects, and the flow of business activities is not dependent on the individual.

\section{REFERENCES}

Bosilj Vukšić, V., Hernaus, T., Kovačić, A., Business process managemant, Školska knjiga, Zagreb, 2008.

Buble, M., Management, EFST, Split, 2000.

Buble. $\mathrm{M}$, The impact of organizational variables on the success of the business processes programme improvement, University of Economics in Split, Split, 2010.

Crosetto, G., Mavazaga, J., The Process-Based Organization-A Natural Organization Strategy, HRD Press, Amherst, 2005. 
Davis, R., Brabander, E., ARIS Design Platform-Getting Started with BPM, Springer, London, 2007.

Džubur, S., Reengineering business processes to achieve business strategy, Thesis, University of Economics Split, Split, 2001.

Galbraith, J. R., Lawler III, E. E. I sur., Organizing for the future, Jossey-Bass, San Francisco, 1993.

Hammer, M., Champy, J., Company reengineering, Mate, Zagreb, 2004.

Hernaus, T., Transformation of classical organization into process-oriented organization, Thesis, University of Economics in Zagreb, Zagreb, 2006.

Markić, B., Tomić, D., Building software agents for market segmentation, Baden Beden, 2006, pp.1 quoted Buble. M., The impact of organizational variables on the success of the business processes programme improvement, University of Economics in Split, Split, 2010.

Milanović, Z., model of business processes re-engineering, FESB, Split, 2005.

Oden, H.W., Transforming the Organization: A Social-Technical Approach, Quorum books, Westport, 1999.

Osterle, H., Business in the Information Age: Heading for New Processes, Springer, Berlin, 1995.

Sikavica, P., Novak, M., Business Organization, Informator, Zagreb, 1999.

www.projektura.org 